\title{
ANALISIS PEMANGKU KEPENTINGAN RANTAI PASOK RUMPUT LAUT INDONESIA BERBASIS SISTEM RESI GUDANG
}

\author{
Stakeholder Analysis of Indonesian Seaweed Supply Chain Based on \\ Warehouse Receipt System
}

\author{
Sutriono Edi, Hermanto Siregar, Lukman Mohammad Baga, Arif Imam Suroso \\ Sekolah Pascasarjana, Sekolah Bisnis, Institut Pertanian Bogor, \\ Jl. Raya Pajajaran, Babakan, Bogor, Jawa Barat 161218, Indonesia \\ E-mail: edisut2000@yahoo.com
}

Naskah diterima: 25/06/2019; Naskah direvisi: 16/08/2019; Disetujui diterbitkan: 02/11/2019

Dipublikasikan online: 31/12/2019

\begin{abstract}
Abstrak
Rantai pasok rumput laut nasional meliputi berbagai tahapan dan subsistem yang terkait satu dengan lainnya. Pemahaman keberadaan dan peran para pemangku kepentingan menjadi penting dalam integrasi pengembangan rumput laut nasional dari hulu ke hilir. Penelitian ini bertujuan untuk memetakan pemangku kepentingan dan menganalisis hubungan antara peran, kepentingan dan kerja sama antara pemangku kepentingan dalam rantai pasok rumput laut nasional berbasis Sistem Resi Gudang (SRG). Analisis hubungan dilakukan melalui metode pemetaan kuadran pemangku kepentingan. Hasil analisis terhadap 15 pemangku kepentingan yang terlibat menunjukkan bahwa koordinasi dan kerja sama antara para pemangku kepentingan dalam rantai pasok masih lemah. Perlu beberapa strategi pendekatan untuk menjaga komunikasi dan koordinasi bagi para pemangku kepentingan terutama pada kuadran IV (closely manage/promoter) yang memiliki kepentingan dan pengaruh tinggi. Strategi penting yang dilakukan adalah melibatkan para pemangku kepentingan tersebut dengan intensif dan memengaruhi mereka secara aktif untuk mendukung integrasi hulu sampai dengan hilir rantai pasok rumput laut. Perlu suatu sistem rantai pasok yang integratif termasuk pemasarannya, serta pemanfaatan sistem Informasi Teknologi (IT) untuk dapat memberikan wadah komunikasi guna sinkronisasi, kerja sama, dan koordinasi antar para pemangku kepentingan dalam mengadapi era revolusi industri 4.0 sehingga rantai pasok pengembangan rumput laut dapat berjalan baik, efisien dan adil bagi semua pihak.
\end{abstract}

Kata kunci: Analisis Pemangku Kepentingan, Sistem Resi Gudang, Kerja Sama, Rantai Pasok Rumput Laut.

\begin{abstract}
The national seaweed supply chain includes various stages and subsystems that are related to one another. Thus, understanding of stakeholders' existence, as well as their role, is important in the integration of national seaweed development from upstream to downstream sides. This paper aims to map the stakeholders and analyze the relationship between roles, interests, and cooperation among stakeholders on the condition of the national seaweed supply chain based on the warehouse receipt system. The relationship analysis among stakeholders used through the stakeholders' quadrant mapping method. The results of the analysis of the 15 stakeholders involved showed that coordination and cooperation between stakeholders in the supply chain for seaweed development still needs to be improved. It is important to approach this matter through strategies in order to maintain communication and coordination for stakeholders, especially in quadrant IV (closely manage' or 'promotors') where their interests are high, and their power is also high. An essential strategy is to involve these stakeholders intensively and actively influence them to continue to support the integration of upstream to downstream seaweed supply chains. Based on this, an integrated supply chain system is needed including marketing and utilization of Information Technology (IT) systems to provide communication channels for synchronization, collaboration, and
\end{abstract}


coordination among stakeholders in industry revolution 4.0 so that the supply chain for seaweed development can run well, efficient and fairly for all parties.

Keywords: Stakeholder Analysis, Warehouse Receipt System, Cooperation, Seaweed Supply Chain

JEL Classification: D2, L5, M10, Q13

\section{PENDAHULUAN}

Rantai pasokan merupakan serangkaian proses alur bisnis yang terdiri dari beberapa lapisan (Hallikas et al, 2004). Manajemen rantai pasok yang efektif akan menjadikan pemasok sebagai mitra melalui rantai perantara untuk industri atau eksportir. Rantai pasok rumput laut penting untuk dilakukan secara efektif dan efisien mengingat adanya resiko terjadinya kelangkaan terhadap bahan baku bagi kelangsungan industri dan perdagangan ekspor. Berdasarkan hasil survei dan data primer dari beberapa pelaku industri pengolahan rumput laut di Sulawesi Selatan ditemukan fakta bahwa terdapat perusahaan pengolahan rumput laut di Makassar yang memproduksi Semi Refined Carrageenan (SRC) berbentuk powder dengan kebutuhan bahan baku rumput laut kering sekitar 200 ton/bulan sudah tidak beroperasi selama sebulan (Desember 2018) karena kurangnya pasokan bahan baku rumput laut dan harga di lapangan yg relatif mahal. Situasi tersebut mengindikasikan pentingnya analisis yang komprehensif terkait sistem logistik rumput laut dengan memperhatikan faktor entitas struktur rantai pasok, tanggungjawab para stakeholder dari sisi sistem input, sistem proses pengolahan, kapasitas produksi, produktivitas dan rendemen, pengolahan produk samping, dan jasa logistik (Sarinah, 2017). Peran dari para pemangku kepentingan dalam hal ini menjadi tinggi dalam keberlangsungan rantai pasok pengembangan bisnis rumput laut.

$$
\text { Yavuz \& Baycan }
$$
menyatakan bahwa partisipasi para pemangku kepentingan merupakan aspek yang sangat penting dalam rantai pasok komoditi pertanian. Rantai pasok suatu komoditi sudah mengalami kompleksitas, oleh karenanya perlu ada mekanisme untuk integrasi dan konektifitas antar pemangku kepentingan dalam rangka mendapatkan hasil keuntungan yang optimal bagi setiap pemangku kepentingan. Rantai pasok rumput laut juga mengalami kompleksitas yang disebabkan adanya jaringan interkoneksi dari pemasok/petani, 
pedagang pengumpul, pedagang besar, eksportir dan industri (Berland et al, 2014). Interaksi yang terjadi diantara para pemangku kepentingan tersebut menciptakan nilai tambah (value added). Dengan demikian diperlukan suatu bisnis yang mampu memahami bagaimana hubungan atar stakeholder tersebut bekerja untuk keberlangsungan bisnis. Apabila suatu bisnis hanya mengelola sebagian pemangku kepentingannya saja, dan mengorbankan pemangku kepentingan lainnya akan berakibat tidak dapat mempertahankan keberlanjutan bisnisnya dalam jangka panjang.

Rantai pasok rumput laut pada penelitian ini diintegrasikan dengan Sistem Resi Gudang (SRG) dan pasarnya (Pasar Lelang). Sistem Resi
Gudang yang selanjutnya disebut SRG sesuai dengan Undang Undang Nomor 9 Tahun 2006 tentang Sistem Resi Gudang sebagaimana telah diubah dengan Undang Undang Nomor 9 Tahun 2011 merupakan instrumen yang mereposisikan kembali komoditas pertanian sebagai suatu barang yang memiliki nilai ekonomis, yang sangat layak untuk dipergunakan sebagai jaminan guna memperoleh kredit dari bank maupun lembaga keuangan nonbank. Dalam undang-undang tersebut tercantum bahwa tujuan dari adanya SRG adalah untuk menjamin dan melindungi kepentingan masyarakat, menjamin kelancaran arus barang, meningkatkan efisiensi biaya distribusi serta menciptakan iklim usaha yang kondusif.

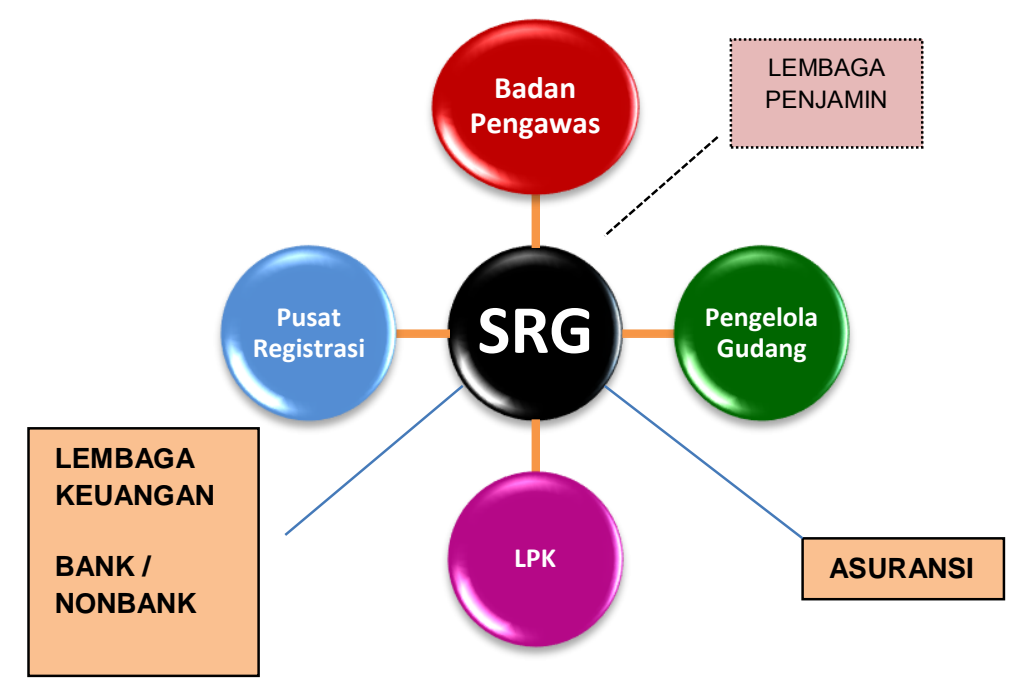

\section{Gambar 1. Para Pemangku Kepentingan pada SRG}

Sumber: Bappebti, Kementerian Perdagangan (2018) 
Resi Gudang sebagai surat berharga ini merupakan dokumen bukti kepemilikan barang di gudang SRG yang dapat dijaminkan ke Lembaga keuangan bank atau non-bank. Implementasi SRG ini perlu terus dikembangkan seperti juga sudah berjalan dengan baik di beberapa negara seperti di India (Shalendra et al, 2016). Gambar 1 adalah para pemangku kepentingan yang terlibat dalam SRG, yaitu Badan Pengawas Berjangka Komoditi (Bappebti), Pengelola Gudang, Pusat Regristasi, Lembaga Penjamin Kesesuaian (LPK), Lembaga Penjamin, Asuransi dan Lembaga Keuangan Baik Bank maupun non Bank.

Peran Bappebti Kementerian Perdagangan (Kemendag) adalah melakukan pembinaan, pengaturan dan pengawasan terhadap kegiatan yg berkaitan dengan SRG. Badan Pengawas SRG ini memberikan persetujuan kepada Pengelola Gudang, LPK dan Pusat Registrasi. Sedangkan peran LPK adalah Lembaga terakreditasi yg melakukan kegiatan seperti membuat penilaian untuk membuktikan bahwa persyaratan tertentu mengenai produk, proses, sistem, dan/atau personalia telah terpenuhi. Kegiatan penilaian kesesuaian dalam SRG dilakukan oleh LPK yg telah mendapat persetujuan Badan Pengawas. Sedangkan peran dari Lembaga Pelaksana Penjaminan Resi Gudang adalah melindungi hak Pemegang Resi Gudang dan/atau Penerima Hak Jaminan serta memelihara stabilitas dan integritas SRG.

Pemangku kepentingan yang berperan penting dalam SRG adalah pengelola gudang yang merupakan badan usaha yang bergerak pada jasa penyimpanan barang dan dapat menerbitkan Resi Gudang. Pengelola Gudang harus Berbentuk Badan Usaha Berbadan Hukum (PT/Koperasi) yg bergerak khusus di bidang jasa pengelolaan gudang dan telah mendapat persetujuan Badan Pengawas. Selanjutnya peran dari Pusat Regristasi adalah suatu Badan Usaha yang melakukan penatausahaan Resi Gudang, berupa pencatatan, penyimpanan, pengalihan, pembebanan hak jaminan, pelaporan, serta penyediaan sistem dan jaringan informasi. Kegiatan sebagai Pusat Registrasi hanya dapat dilakukan oleh badan usaha berbadan hukum dan telah mendapat persetujuan Badan Pengawas. Peran dari masing-masing pemangku kepentingan tersebut perlu 
dianalisis dalam rangka pemetaan perannya pada integrasi rantai pasok bisnis rumput laut dari hulu sampai dengan hilir.

Bryson (2003) menyatakan bahwa analisis pemangku kepentingan ini menjadi lebih penting dari sebelumnya seiring dengan meningkatnya saling keterkaitan antara komoditi dengan pengelolaan sumber daya alam yang dapat berdampak pada sejumlah orang, kelompok, dan/atau organisasi. Selanjutnya Solaimani et al. (2013) menyatakan bahwa analisis pemangku kepentingan dapat digunakan untuk mengurangi kompleksitas antar pemangku kepentingan. Dengan analisis tersebut, dapat dilakukan identifikasi siapa saja yang terlibat dalam rantai suplai bisnis rumput laut di Indonesia, peran apa saja yang dilakukan oleh masing-masing stakeholder dalam mengoptimalkan fungsinya dalam mewujudkan pengelolaan-pengelolaan secara terpadu. SDM yang menjadi aktor pada rantai suplai rumput laut penting untuk dikelola dan dikembangkan melalui kebijakan-kebijakan yang secara aktif dengan melibatkan para pemangku kepentingan yang terlibat langsung maupun tidak langsung secara optimal (Khan et al., 2012).
Penelitian ini bertujuan untuk memetakan pemangku kepentingan rantai pasok rumput laut menurut tingkat kepentingan (interest) dan pengaruh/ kekuatan (power) bagi masing masing pemangku kepentingan di dalam mata rantai dari hulu serta hilir baik pelaku usaha maupun pemerintah Daerah dan Pusat. Output dari tulisan ini adalah diperolehnya pemetaan masing-masing pemangku kepentingan terhadap tingkat kepentingan (interest) dan pengaruh (power) dalam rantai pasok pengembangan komoditi rumput laut berbasis SRG.

\section{METODOLOGI}

Penelitian dilakukan di wilayah Sulawesi Selatan yang merupakan penghasil utama rumput laut di Indonesia dan saat ini merupakan lokasi satu-satunya implementasi SRG rumput laut di Indonesia. Penelitian dilakukan pada Agustus 2018 hingga Februari 2019 dengan beberapa tahapan yang dilakukan sebagai berikut:

\section{Identifikasi Responden}

Banyak perbedaan pendapat tentang siapa atau apa pemangku kepentingan. Kata pemangku kepentingan atau stakeholder muncul pada abad ke-17 (tujuh belas). Selanjutnya teori stakeholder tersebut berkembang dengan definisi-definisi 
yang lebih sempit dan lebih bersifat instrumen sebagai kelompok atau individu dalam suatu organisasi. Selain itu terdapat pula pandangan yang lebih luas dan lebih normatif yang mendefinisikan pemangku kepentingan sebagai "entitas alami yang dipengaruhi oleh kinerja organisasi" (Reed et al., 2009).

Dalam implementasinya, istilah pemangku kepentingan juga digunakan untuk mendeskripsikan komunitas atau organisasi yang menerima dampak dari aktivitas atau kebijakan, dimana suatu pihak tidak selalu menerima dampak secara adil. Sebagian pihak mungkin menanggung biaya dan sebagian lainnya justru memperoleh manfaat dari suatu kegiatan atau kebijakan (Race \& Millar, 2008). Bryson (2004) mendefinisikan pemangku kepentingan adalah setiap individu atau kelompok yang dapat memberi dampak atau yang terkena dampak oleh keberhasilan tujuan suatu organisasi. Hal tersebut bisa berdasarkan kebijakan, program, atau aktivitas pembangunannya. Setiap kelompok ini memiliki sumber daya dan kebutuhan masing-masing yang harus terwakili dalam proses pengambilan keputusan dalam kegiatan pembangunan. Hermans \& Thiesen (2008) menegaskan bahwa setiap aktor membawa kepentingan masing-masing yang bisa berbeda satu dengan yang lainnya dan menyebabkan terjadinya celah informasi di antara para aktor. Proses pengambilan keputusan tidak dapat dilaksanakan secara efektif oleh hanya satu kelompok tertentu (Gonsalves et al., 2005).

Partisipasi pemangku kepentingan dalam menunjang keberhasilan suatu program/kegiatan mempunyai peranan penting dimana terdapat empat alasan dari hal tersebut (Iqbal, 2007). Pertama, partisipasi diperlukan untuk meningkatkan rencana pengembangan program/kegiatan secara umum dan kegiatan prioritas secara khusus. Kedua, partisipasi memiliki tujuan agar implementasi kegiatan berjalan sesuai dengan kebutuhan masyarakat. Ketiga, partisipasi diperlukan untuk menjamin keberlangsungan kegiatan. Keempat, partisipasi dapat meningkatkan kesetaraan dalam implementasi kegiatan. Pelaksanaan peran yang berbeda dari para pemangku kepentingan dapat saling melengkapi untuk mencapai tujuan, sebaliknya jika tidak dilakukan dengan baik akan berdampak pada kinerja mereka dalam mencapai tujuan program, sementara kinerja dipengaruhi oleh kapasitas (Raydais \& Damayanti, 2018). 
Berdasarkan studi literatur tersebut pemangku kepentingan yang terlibat dalam sistem resi gudang dan pengembangan rantai pasok rumput laut adalah yang dijadikan sebagai responden dalam menggali data dan informasi. Para responden memuat semua pemangku kepentingan pada sistem resi Gudang seperti pada Gambar 1. Responden berasal dari Badan Pengawas yaitu Bappebti, pusat regristrasi dalam hal ini adalah Kliring Berjangka Indonesia, pengelola gudang, Lembaga penjamin kesesuaian, Lembaga bank dan non bank. Selain pemangku kepentingan kelembagaan pada Sistem resi Gudang juga ditambahkan pemangku kepentingan yang terlibat dalam rantai pasok pengembangan rumput laut sebagai responden, yaitu petani, asosiasi pengolahan industri berbasis rumput laut, bursa berjangka, eksportir dan dinas atau pemerintah daerah.

\section{Analisis dan Pemetaan Pemangku Kepentingan \\ Analisis pada penelitian ini} dilakukan dengan metode deskriptif. Metode ini dikembangkan dengan mempelajari permasalahan dari obyek yang diteliti, sehingga diketahui faktorfaktor strategik yang berpengaruh dalam upaya pengembangan rumput laut berbasis Sistem Resi Gudang. Data yang digunakan dalam penelitian ini adalah data primer dan data sekunder.

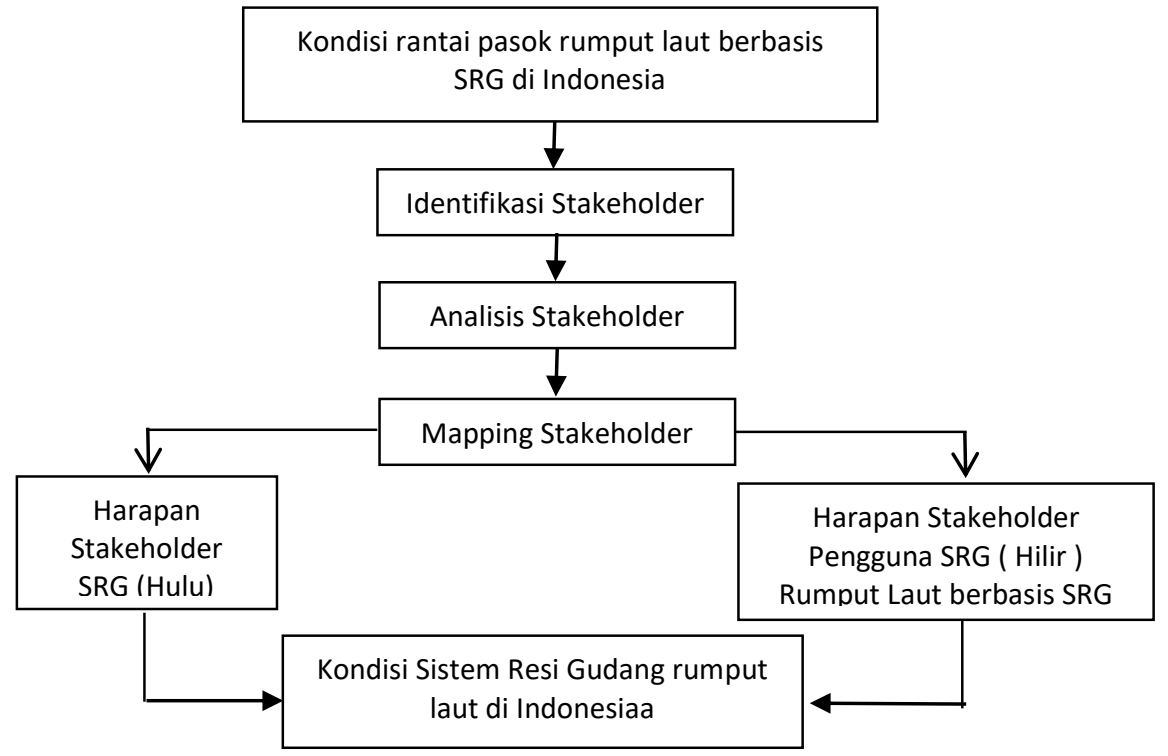

\section{Gambar 2. Kerangka pemikiran penelitian}


Dalam realisasi yang berkembang, para pemangku kepentingan dapat memengaruhi keberhasilan suatu pengelolaan dengan menggunakan pendekatan Analisis Stakeholder. Analisis ini dapat digunakan untuk memahami kepentingan (interest) dan pengaruh (power) mereka, dan bagaimana hal ini dapat mendukung atau mengancam kinerja suatu pengelolaan (Brugha \& Varvasovszky, 2000). Dalam kebijakan pengelolaan sumber daya alam, analisis pemangku kepentingan dilihat sebagai sebuah pendekatan yang dapat memberdayakan para pemangku kepentingan untuk memengaruhi proses pengambilan keputusan (Reed et al., 2009), dan dalam penelitian kebijakan analisis stakeholder telah dilihat sebagai suatu cara untuk menghasilkan informasi tentang "aktor yang relevan" untuk memahami perilaku, minat, agenda, dan pegaruh mereka pada proses pengambilan keputusan (Brugha \& Varvasovszky, 2000). Analisis stakeholder juga digunakan untuk memahami beragam kepentingan stakeholder yang berpotensi bertentangan (Hubacek et al., 2007).
Reed et al, 2009 menyatakan bahwa analisis pemangku kepentingan dilakukan dengan tahapan berikut ini.

1. Mengidentifikasi pemangku kepentingan kunci dari kelompok atau individu yang kemungkinan memiliki potensi memberi dampak atau terkena dampak dalam proses integrasi SRG dengan pasarnya dengan menggunakan kuesioner semi terstruktur. Dalam proses identifikasi ini juga digali peran para pemangku kepentingan berdasarkan tugas pokok dan fungsi yang diemban oleh instansi terkait.

2. Mengkategorisasikan pemangku kepentingan ke dalam kelompok (pemangku kepentingan kunci dan pemangku kepentingan pendukung). Dalam analisis ini dilakukan penafsiran matriks kepentingan dan pengaruh/kekuatan para pemangku kepentingan terhadap integrasi SRG dengan pasarnya yang dinyatakan secara kuantitatif (skoring) dan dikelompokkan berdasarkan kriteria kepentingan dan pengaruh para pemangku kepentingan tersebut. Prosedur tersebut mengacu pada modifikasi model yang dikembangkan oleh (Roslinda et al., 2012), 
3. Mengetahui hubungan antar yang mengindikasikan tingginya pemangku kepentingan dengan menggunakan Actor-Linkage pengaruh stakeholders terhadap Matrix. Penilaian hubungan pengembangan rantai pasok komoditi kontekstual matrik perbandingan berpasangan aktor menggunakan kriteria $0=a d a$ hubungan dan 1=tidak ada hubungan. Dalam analisis ini para pemangku kepentingan ditabulasi ke dalam matriks dua dimensi dan hubungan antar-para pemangku kepentingan digambarkan dengan menggunakan rata-rata nilai dari hasil penilaian para pakar dengan menggunakan skala likert 1 sd 5 .

4. Pembobotan untuk mendapatkan agregrasi nilai pendapat pakar dalam menentukan stakeholder mapping adalah dengan menggunakan rumus sebagai berikut (Hikmah, 2016):

$$
x=\frac{\sum_{i=1}^{n} x_{i} f_{i}}{\sum_{i=1}^{n} f_{i}}
$$

Dimana : $x=$ nilai agegrasi pakar $x_{i}=$ bobot penilaian pakar $f_{i}=$ frekuensi pakar

Pemetaan pemangku kepentingan dikelompokkan dalam empat kuadran. kelompok promotor/manage closely rumput laut berbasis SRG dan tingkat ketertarikan yang tinggi terhadap ide tersebut. Kelompok Laten/Keep Satisfied yang mengindikasikan tingginya pengaruh stakeholders pengembangan rantai pasok komoditi rumput laut berbasis SRG, namun mempunyai tingkat ketertarikan yang rendah terhadap ide tersebut. Kelompok Apathetics/Monitor yang mengindikasikan rendahnya pengaruh stakeholders terhadap pengembangan rantai pasok komoditi rumput laut berbasis SRG dan tingkat ketertarikan yang rendah terhadap ide tersebut. kemudian Kelompok Defenders/Keep informed yang mengindikasikan dengan pengaruh stakeholders terhadap Kelompok Defenders yang mengindikasikan rendahnya pengaruh stakeholders terhadap pengembangan rantai pasok komoditi rumput laut berbasis SRG, namun mempunyai tingkat ketertarikan yang tinggi terhadap ide tersebut. Keempat kuadran tersebut dapat dilihat pada Gambar 3. 


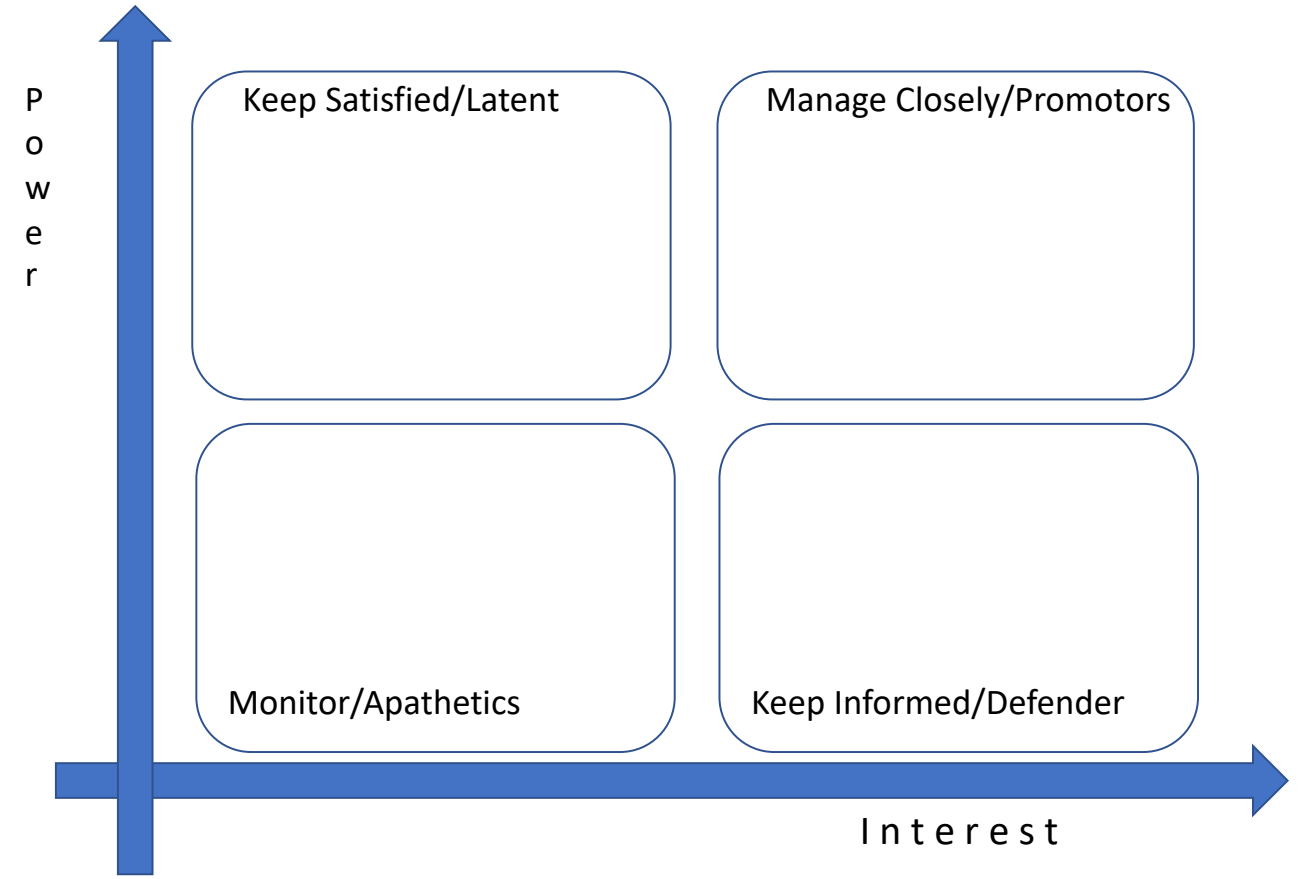

\section{Gambar 3. Kuadran Pemetaan Stakeholders}

Sumber: Reed et al (2009)

Merujuk pada Nurfatriani et. al. (2015), derajat kepentingan atau sumbu $x$ dengan skala likert, dengan skor 1 sampai dengan 5 , dihitung berdasarkan kriteria berikut ini.

a. Skor 5=Sangat Tinggi: memiliki harapan, aspirasi dan manfaat potensial yang sangat tinggi atas terwujudnya kebijakan pengembangan rantai pasok rumput laut berbasis resi gudang.

b. Skor 4=Tinggi: memiliki harapan, aspirasi dan manfaat potensial yang tinggi atas terwujudnya kebijakan pengembangan rantai pasok rumput laut berbasis resi gudang.

c. Skor 3=Sedang: memiliki harapan dan aspirasi tetapi tidak menerima manfaat potensial secara langsung dari terwujudnya kebijakan pengembangan rantai pasok rumput laut berbasis resi gudang.

d. Skor 2=Rendah: Sedikit memiliki harapan, aspirasi dan manfaat potensial atas terwujudnya kebijakan pengembangan rantai pasok rumput laut berbasis resi gudang.

e. Skor 1=Sangat rendah: tidak memiliki harapan, aspirasi dan manfaat potensial atas terwujudnya kebijakan pengembangan rantai pasok rumput laut berbasis resi gudang.

Sedangkan derajat pengaruh atau sumbu y derajat pengaruh 
dipertimbangkan dengan skala likert 1 sampai dengan 5 , sebagai berikut:

a. Skor 5=Sangat Tinggi: memiliki kewenangan mutlak dalam membuat kebijakan, memfasilitasi implementasi kebijakan dan memengaruhi pihak lain dalam membuat kebijakan pengembangan rantai pasok rumput laut berbasis resi gudang.

b. Skor 4=Tinggi: memiliki kewenangan penuh dalam membuat kebijakan, memfasilitasi implementasi kebijakan dan memengaruhi pihak lain dalam membuat kebijakan pengembangan rantai pasok rumput laut berbasis resi gudang.

c. Skor 3=Sedang: memiliki kewenangan yang terbatas dalam membuat kebijakan, memfasilitasi implementasi kebijakan dan memengaruhi pihak lain dalam membuat kebijakan pengembangan rantai pasok rumput laut berbasis resi gudang.

d. Skor 2=Rendah: sedikit memiliki kewenangan dalam membuat kebijakan, memfasilitasi implementasi kebijakan dan memengaruhi pihak lain dalam membuat kebijakan pengembangan rantai pasok rumput laut berbasis resi gudang. e. Skor 1=Sangat Rendah: tidak memiliki kewenangan dalam membuat kebijakan, memfasilitasi implementasi kebijakan dan memengaruhi pihak lain dalam membuat kebijakan pengembangan rantai pasok rumput laut berbasis resi gudang.

Pengumpulan informasi dilakukan melalui wawancara mendalam dengan beberapa ahli. Saat melakukan wawancara dipandu dengan daftar pertanyaan dan pengisian kuesioner pemetaan pemangku kepentingan. Para ahli diminta menjawab dan membandingkan peran pemangku kepentingan berdasarkan kepentingan dan pengaruhnya dengan penilaian 1 sampai dengan 5 . Hasil penilaian dari beberapa ahli tersebut terhadap suatu fokus pemetaan pemangku kepentingan maka dilakukan penghitungan rata-rata untuk mendapatkan posisi pemetaan pemangku kepentingan.

Pada penelitian ini pengumpulan informasi dilakukan kepada sejumlah responden yang ditentukan secara sengaja (purposive sampling) yaitu narasumber ahli dengan jumlah 15 orang. Tabel 1 adalah klasifikasi daftar narasumber ahli yang menjadi responden penelitian. 
Tabel 1. Klasifikasi Narasumber Indepth Interview Terstruktur

\begin{tabular}{|c|c|c|}
\hline No & Narasumber & Jumlah \\
\hline \multirow[t]{4}{*}{1} & Pemerintah & \\
\hline & Kementerian Perdagangan & 3 \\
\hline & Kemenko Perekonomian & 1 \\
\hline & $\begin{array}{l}\text { Lembaga Penguji Mutu } \\
\text { Barang }\end{array}$ & 1 \\
\hline \multirow[t]{3}{*}{2} & Perbankan & \\
\hline & Bank Indonesia & 1 \\
\hline & Bank BJB & 1 \\
\hline 3 & $\begin{array}{l}\text { Asosiasi Rumput } \\
\text { Laut/Trader }\end{array}$ & 1 \\
\hline 4 & $\begin{array}{l}\text { Pengelola Gudang SRG } \\
\text { (Koperasi)/Asosiasi Petani } \\
\text { Rumput Laut }\end{array}$ & 1 \\
\hline \multirow[t]{4}{*}{5} & Swasta & \\
\hline & Bursa Berjangka Komoditi & 1 \\
\hline & e-commerce pertanian & 1 \\
\hline & $\begin{array}{l}\text { Industri Pengolah Rumput } \\
\text { Laut }\end{array}$ & 2 \\
\hline \multirow[t]{2}{*}{6} & $\begin{array}{l}\text { BUMN (Pusat Registrasi } \\
\text { SRG) }\end{array}$ & \\
\hline & $\begin{array}{l}\text { PT Kliring Berjangka } \\
\text { Indonesia }\end{array}$ & 1 \\
\hline \multirow[t]{2}{*}{7} & Eksportir & 1 \\
\hline & TOTAL & 15 \\
\hline
\end{tabular}

\section{HASIL DAN PEMBAHASAN}

Identifikasi Pemangku Kepentingan

Dalam identifikasi pemangku kepentingan terlebih dahulu dilakukan penelaahan terhadap rantai pasok rumput laut dilakukan dengan survei pada industri pengolahan dan melakukan wawancara dengan pihak terkait untuk memperoleh gambaran umum rantai pasokan dan risiko. Dalam struktur rantai pasok industri pengolahan rumput laut di Sulawesi Selatan menunjukkan bahwa rantai pasok rumput laut di mulai dari petani, pedagang di tingkat petani, pengumpul sedang, pedagang besar, eksportir/industri seperti struktur rantai pasok yang disajikan pada Gambar 3 . Rantai pasok rumput laut sudah melihat kajian hasil penelitian terdahulu yang dilakukan oleh Sarinah dan Djatna (2015) yang dimodifikasi dengan penambahan Sistem Resi Gudang sebagai salah satu mata rantai pasoknya. Berdasarkan hasil survei lapangan pada Gambar 4, terdapat peran penting SRG dalam alternatif rantai penjualan rumput laut bagi kelompok tani/Koperasi yang memanfaatkan skema tunda jual guna memperoleh harga yang lebih baik dalam periode waktu tertentu di kemudian hari (2- 4 bulan). 


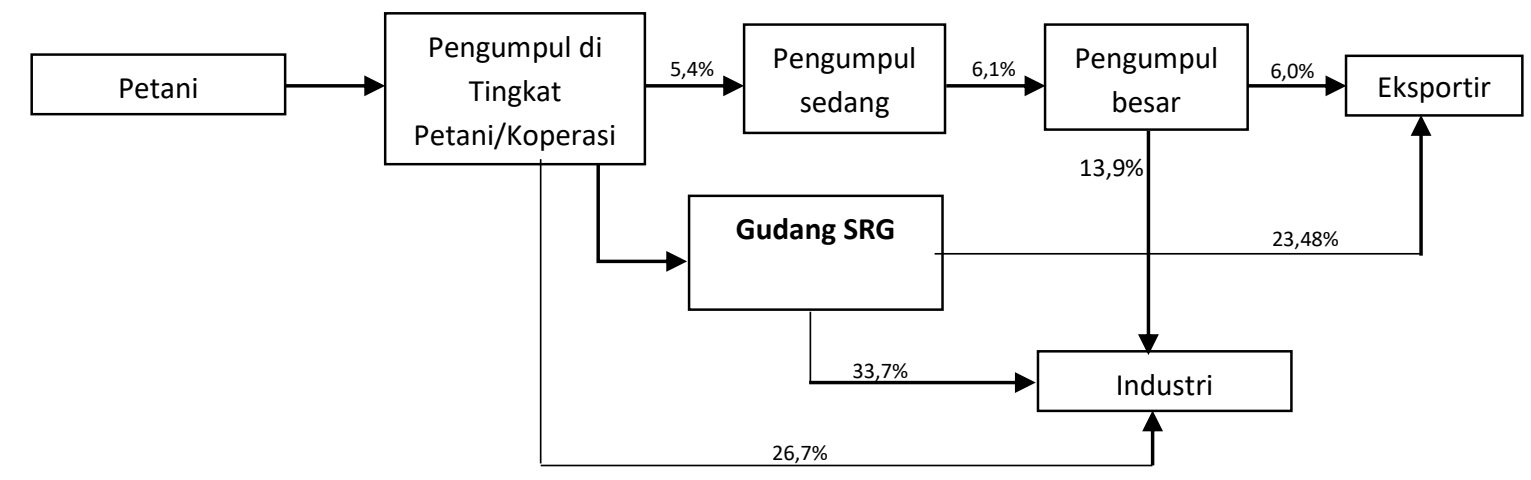

\section{Gambar 4. Struktur Rantai Pasok Rumput Laut pada Industri Pengolahan Rumput Laut di Sulawesi Selatan}

Berdasarkan Gambar 4 dapat dijelaskan mengenai persentasi kenaikan harga di setiap tingkat rantai pasok. Harga penjualan rumput laut di tingkat petani dipengaruhi oleh siapa yang membeli. Harga Cottonii ditingkat petani berkisar antara Rp20.000 sampai dengan Rp24.000, sedangkan harga Glacilaria berkisar antara Rp6.500 sampai dengan Rp7.500. perbedaan harga jual petani ini dipengaruhi oleh tipe rantai pasoknya. Semakin panjang rantai pasok, maka harga jual di tingkat petani semakin kecil, dan sebaliknya semakin pendek rantai pasoknya maka harga jual di tingkat petani semakin besar. Terdapat tiga tipe rantai pasok rumput laut. Rantai pasok tipe 1 alur penjualan rumput laut terdiri dari (1) dari petani dijual ke pengumpul di tingkat petani/koperasi, kemudian (2) dari pengumpul di tingkat petani/koperasi ke pengumpul sedang, selanjutnya (3) dari pengumpul sedang ke pengumpul besar dan (4) berakhir di eksportir atau industri. Marjin penjualan dari masingmasing tahapan rantai pasok tersebut secara berurutan $(1)=5,4 \%,(2)=6,1 \%$, (3-eksportir) $=6,0 \%$ dan (3-industri) $=13,9 \%$.

Rantai pasok tipe 2 alur penjualan rumput laut terdiri dari (1) dari petani dijual ke pengumpul di tingkat petani/koperasi, (2) koperasi atau kelompok tani melakukan tunda jual (selama 3 bulan) dengan SRG, dan (3) dari Gudang SRG ke Industri atau eksportir. Marjin yang diperoleh oleh kelompok tani atau koperasi jika dijual ke eksportir sebesar $23,48 \%$ dan jika dijual ke Industri sebesar 33,7\% dengan asumsi dalam 3 (tiga) bulan terjadi kenaikan harga sebesar 25\% (standard mutu komoditi SRG harus memenuhi 
SNI rumput laut). Selanjutnya tipe 3 adalah koperasi atau kelompok tani menjadi binaan Industri, maka mereka bisa langsung menjual hasil budidaya rumput laut ke Industri dengan marjin sebesar $26,7 \%$ dengan persyaratan mutu tinggi yang ketat sesuai standard industri. Besaran marjin sangat dipengaruhi oleh harga jual rumput laut kering. Semakin pendek rantai distribusi/pemasarannya maka keuntungan marjin nya semakin besar. Mekanisme SRG memberikan peluang untuk mendapatkan tambahan marjin dengan tunda jual yang dilakukan. Dalam tiga bulan kedepan jika harga rumput laut kering naik, maka akan mendapatkan selisih keuntungan dari naiknya harga tersebut.

Identifikasi pemangku kepentingan pada rantai pasok bisnis rumput laut berbasis Sistem Resi Gudang adalah terdiri dari (1) Pemerintah Pusat, (2) Pemerintah Daerah, (3) Petani Rumput Laut, (4) Pengelola Sistem Resi Gudang, (5) Pengumpul lokal, (6) Trader/Eksportir, (7) Asosiasi Rumput Laut, (8) Industri pengolah Rumput laut, (9) Kliring Berjangka Indonesia/Pusat Registrasi, (10) Lembaga Penilai Kesesuaian, (11) Lembaga keuangan bank, (12) Lembaga keuangan non bank, (13) Penyelenggara Pasar Lelang Komoditi, (14) Masyarakat dan (15) Bursa Berjangka Komoditi. Atribut atau pemetaan pemangku kepentingan serta pemahaman mereka terhadap objek berpengaruh penting dan diidentifikasi sebagai kunci keberhasilan suatu proyek (Rajablu et al., 2018).

\section{Tabel 2. Pengategorisasian Pemangku Kepentingan Pada Penentuan Kebijakan}

\section{Rantai Pasok Bisnis Rumput Laut Berbasis SRG}

\begin{tabular}{lll}
\hline No & \multicolumn{1}{c}{ Pemangku Kepentingan } & \multicolumn{1}{c}{ Keterangan } \\
\hline 1 & Pemerintah Pusat & Pemangku Kepentingan Kunci \\
2 & Pemerintah Daerah & Pemangku Kepentingan Pendukung \\
3 & Petani Rumput Laut & Pemangku Kepentingan Kunci \\
4 & Pengelola Sistem Resi Gudang & Pemangku Kepentingan Kunci \\
5 & Pengumpul lokal & Pemangku Kepentingan Pendukung \\
6 & Trader/Eksportir & Pemangku Kepentingan Kunci \\
7 & Asosiasi Rumput Laut & Pemangku Kepentingan Pendukung \\
8 & Industri pengolah Rumput laut & Pemangku Kepentingan Kunci \\
9 & Kliring Berjangka Indonesia/Pusat Regristasi & Pemangku Kepentingan Kunci \\
10 & Lembaga Penilai Kesesuaian & Pemangku Kepentingan Kunci \\
11 & Lembaga keuangan bank & Pemangku Kepentingan Kunci \\
12 & Lembaga keuangan non bank & Pemangku Kepentingan Kunci \\
13 & Penyelenggara Pasar Lelang Komoditi & Pemangku Kepentingan Pendukung \\
14 & Masyarakat & Pemangku Kepentingan Pendukung \\
15 & Bursa Berjangka Komoditi & Pemangku Kepentingan Pendukung \\
\hline
\end{tabular}


Setelah dilakukan identifikasi kepentingan agar dampak penelitian pemangku kepentingan, selanjutnya terhadap kebijakan dapat dilakukan analisis pemangku dimaksimalkan. kepentingan yang digunakan untuk mengidentifikasi semua pihak yang terlibat dalam proses rantai pasok bisnis rumput laut berbasis SRG, pemangku kepentingan yang membuat atau melaksanakan kebijakan, dan berbagai pihak perantara diantara kedua pihak. Pemetaan pemangku kepentingan sangat membantu dalam menentukan cara untuk menarik perhatian pemangku

\section{Selanjutnya Analisis Pemangku} Kepentingan dengan menghitung ratarata penilaian dari para pakar terhadap pemangku kepentingan yang terlibat di dalam rantai pasok bisnis rumput laut berbasis SRG di Indonesia. Penilaian terhadap tingkat kepentingan dan pengaruh dari masing-masing pemangku kepentingan dapat dilihat pada Tabel 3.

\section{Tabel 3. Penilaian Tingkat Kepentingan dan Pengaruh dari Masing-masing Pemangku Kepentingan Pada Rantai Pasok Bisnis Rumput Laut Berbasis SRG di Indonesia}

\begin{tabular}{llcc}
\hline No & \multicolumn{1}{c}{ Pemangku Kepentingan } & $\begin{array}{c}\text { Nilai Pengaruh } \\
\text { (Power) }\end{array}$ & $\begin{array}{c}\text { Nilai Kepentingan } \\
\text { (Interest) }\end{array}$ \\
\hline 1 & Pemerintah Pusat & 4,65 & 4,67 \\
2 & Pemerintah Daerah & 3,22 & 2,22 \\
3 & Petani Rumput Laut & 4,23 & 4,21 \\
4 & Pengelola Sistem Resi Gudang & 4,21 & 4,33 \\
5 & Pengumpul lokal & 2,32 & 3,34 \\
6 & Trader/Eksportir & 3,22 & 3,56 \\
7 & Asosiasi Rumput Laut & 2,12 & 3,34 \\
8 & Industri pengolah Rumput laut & 3,32 & 3,33 \\
9 & Kliring Berjangka Indonesia/Pusat & 4,32 & 4,12 \\
& Regristasi & & \\
10 & Lembaga Penilai Kesesuaian & 4,22 & 2,21 \\
11 & Lembaga keuangan bank & 3,32 & 2,32 \\
12 & Lembaga keuangan non bank & 3,34 & 2,65 \\
13 & Penyelenggara Pasar Lelang Komoditi & 3,55 & 3,34 \\
14 & Masyarakat & 1,23 & 1,55 \\
15 & Bursa Berjangka Komoditi & 1,00 & 3,00 \\
\hline
\end{tabular}

Pemetaan para pemangku kepentingan dibuat di dalam matriks yang berbeda menurut kepentingan dan pengaruh mereka. "Kepentingan" menunjukkan sejauh mana mereka kemungkinan besar akan terpengaruh oleh objek penelitian atau perubahan kebijakan, dan seberapa besar kepentingan atau kepedulian mereka terhadap atau tentang objek penelitian atau perubahan kebijakan. "Pengaruh" mengukur pengaruh yang mereka miliki 
atas objek penelitian atau kebijakan, atau seberapa jauh mereka dapat mendukung atau menghambat tercapainya perubahan yang diingin. Penilaian terhadap tingkat Kepentingan dan tingkat pengaruh berdasarkan rentang nilai 1 sampai dengan 5 , atau skala likert. Agregrasi pemetaan pemangku kepentingan dilakukan dengan melakukan rata-rata hasil penilaian terhadap jumlah ahli yang menilai. Dengan demikian didapatkan matrik pemetaan pemangku kepentingan.
Pemetaan dilakukan untuk mengetahui peran masing-masing stakeholder dalam rantai pasok bisnis rumput laut berbasis SRG di Indonesia. Terdapat empat kuadran dalam melakukan analisis stakeholder yang dibedakan menjadi empat kuadran, yang terdiri dari kuadran 1 dinamakan Apathetic, kuadran II dinamakan Defender, Kuadran III dinamakan Latent dan kuadran IV dinamakan Promoter. Gambar 5 menunjukkan peta kuadran pemetaan pemangku kepentingan.

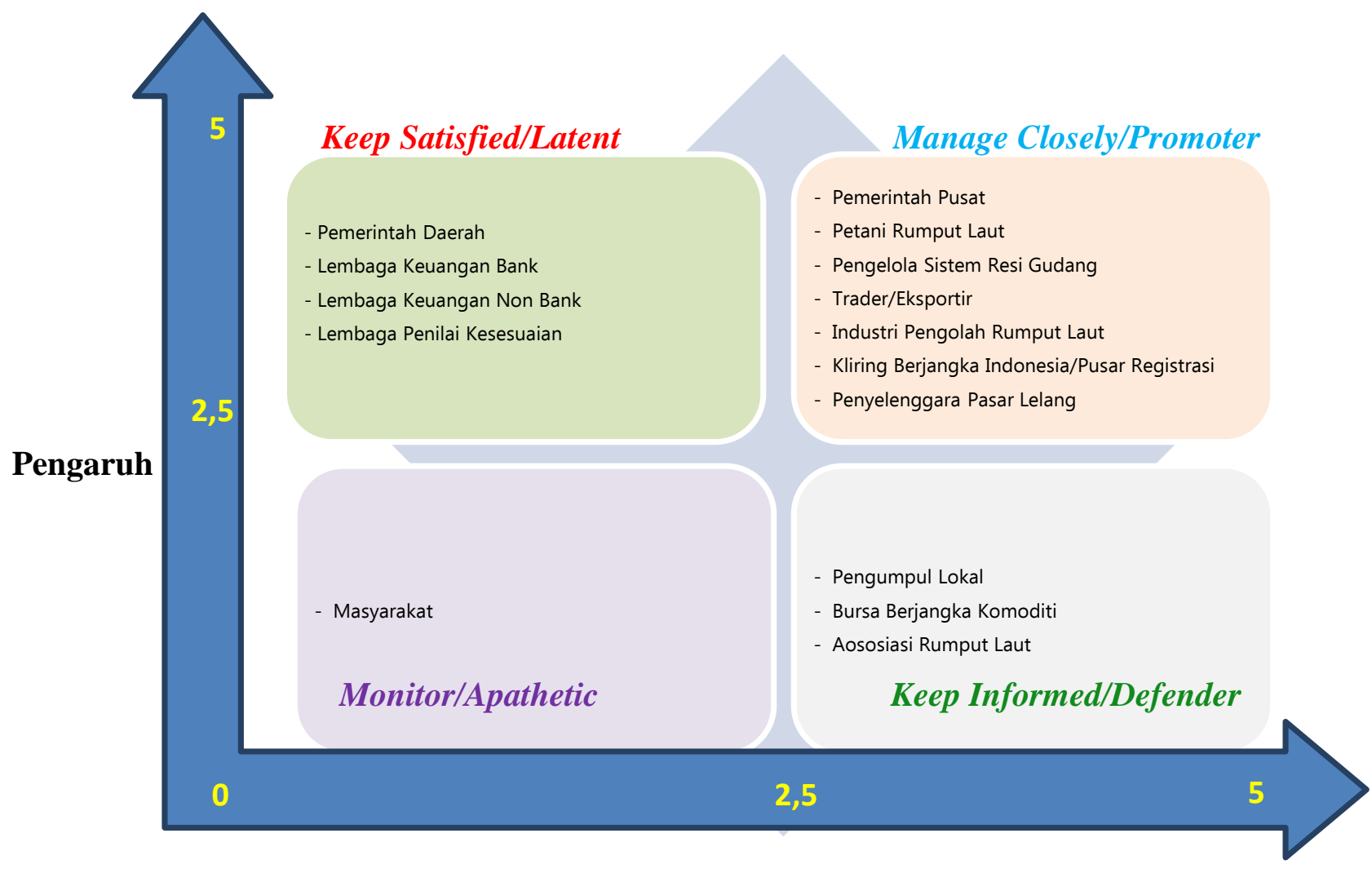

Kepentingan

Gambar 5. Peta Kuadran Pemangku Kepentingan 
Dari hasil pengolahan data memiliki kepentingan tinggi dan menggunakan matriks kepentingansekaligus memiliki kewenangan tinggi pengaruh (interest power matrix) seperti yang disajikan pada Gambar 5, pemangku kepentingan untuk setiap kategori dalam rantai pasok bisnis rumput laut berbasis SRG di Indonesia terdiri atas:

- Promoter. Pemerintah Pusat, Petani Rumput laut, Pengelola Gudang, Trader/Eksportir, industry Pengolah

Rumput Laut dan Kliring Berjangka Indonesia/Pusat Regristasi dan

Penyelenggara Pasar Lelang

- Defender. Pengumpul Lokal dan Bursa Berjangka Komoditi

- Latent. Pemerintah daerah, Lembaga Keuangan Bank, Lembaga Keuangan Non Bank dan Lembaga Penilai Kesesuaian

- Apathetic: Penyelenggara Pasar Lelang, Asosiasi Rumput Laut dan Masyarakat.

Berdasarkan penilaian tingkat kepentingan dan pengaruh dari masingmasing pemangku kepentingan pada rantai pasok bisnis rumput laut berbasis SRG di Indonesia maka uraian analisis pemetaan pemangku kepentingan tersebut yakni sebagai berikut:

\section{Manage Closely/Promoters}

Pada kuadran IV (Gambar 5) terlihat bahwa lembaga-lembaga yang

pada integrasi SRG rumput laut dengan pasarnya. Para pemangku kepentingan tersebut antara lain: pemerintah pusat, petani rumput laut, pengelola SRG, traderleksportir, industri pengolah rumput laut, kliring berjangka Indonesia/pusat regristasi dan penyelenggara pasar lelang.

Pemerintah Pusat dalam hal ini adalah Badan Pengawas Perdagangan Berjangka Komoditi, Kemendag sudah melakukan pembinaan dan pengawasan terhadap kinerja SRG. Volume komoditi Resi Gudang periode tahun 2008-2018 (sampai 30 September 2018) mencapai 97.000,53 ton dengan nilai Rp577.053.300.507,(Bappebti, 2018). Sementara pembiayaan yang dikeluarkan melalui SRG ini sebesar Rp331.999.797.193. Jumlah resi gudang yang diterbitkan sebanyak 2.874 resi.

Bappebti berwenang membuat kebijakan terkait komoditi yang dapat di resi gudangkan melalui Peraturan Menteri Perdagangan nomor 37 tahun 2011 yang menetapkan bahwa komoditi untuk bisa masuk dalam komoditi SRG, syaratnya adalah harus memenuhi standar mutu yang ditentukan (SNI), daya simpannya minimal 3 bulan dan 
jumlah minimum komoditi yang sudah membangun 121 gudang SRG di disimpan. berbagai daerah di Indonesia. Namun

Berdasarkan Peraturan Menteri Perdagangan Nomor 37/M-DAG/ PER/11/2011 tentang Barang yang dapat disimpan di Gudang dalam Penyelenggaraan Sistem Resi Gudang, komoditi yang dapat disimpan di gudang SRG berjumlah 17 jenis, antara lain gabah, beras, jagung, kopi, kakao, lada, karet, rumput laut, rotan, garam, gambir, sebanyak 31 gudang diantaranya masih belum berjalan karena beberapa kendala. Salah satu kendala yang dihadapi adalah belum terintegrasinya rantai pasok antara hulu dan hilir termasuk pasarnya dalam pengembangan komoditi pertanian. Selanjutnya adalah Pengelola Gudang yang dapat menerbitkan Sistem Resi teh, kopra, timah, bawang merah, ikan, Gudang. Proses penerbitan Resi dan pala. Pembinaan SRG yang sudah Gudang dapat dilihat pada Gambar 6. dilakukan sampai dengan tahun 2018

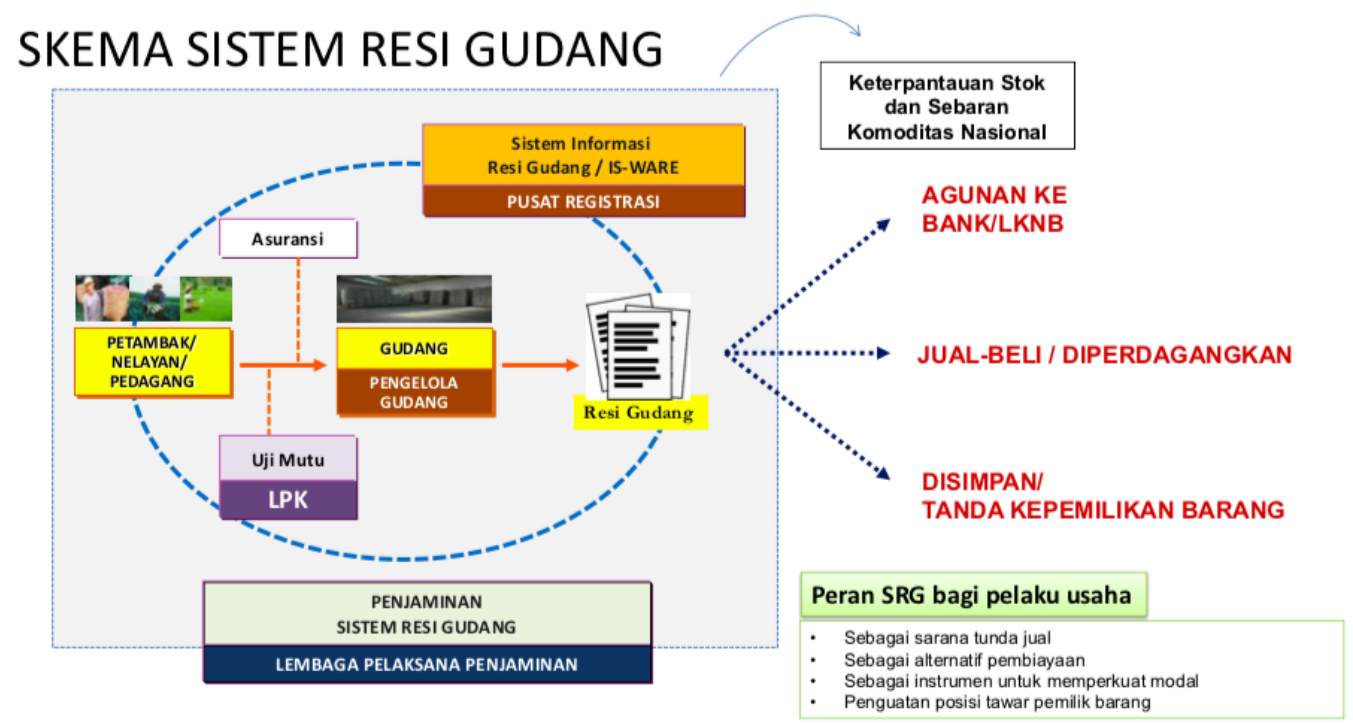

\section{Gambar 6. Proses Penerbitan Resi Gudang}

Sumber: Bappebti, Kementerian Perdagangan (2018)

Penerbitan resi gudang dilakukan oleh pengelola gudang yang sudah mendapatkan ijin dari Badan Pengawas Perdagangan Berjangka Komoditi.
Kendala yang dihadapi di pemangku kepentingan gudang ini adalah adanya keterbatasan Calon Pengelola Gudang di daerah yang memenuhi syarat 
kecukupan Modal serta mampu melakukan pengelolaan dan pemasaran komoditas (integrasi bisnis). Pengelola gudang perlu inovasi jemput bola untuk mengoptimumkan kapasitas gudang dan memkasimumkan operasional pergudangan. Berdasarkan data Bappebti terakhir (2019), transaksi Resi Gudang untuk komoditi rumput laut yang dikelola oleh Pengelola Gudang (koperasi) menunjukkan peningkatan pesat pada tiga tahun terakhir yakni pada tahun $2016 \quad$ senilai Rp150.000.000,-, tahun 2017 sebesar Rp4.706.155.008,- dan tahun 2018 sejumlah Rp18.382.500.000,-

Petani rumput laut adalah pemangku kepentingan yang menjadi kunci dari integrasi rantai pasok dari hulu sampai dengan hilir berbasis pembiayaan sistem resi gudang. Petani rumput laut sering mengeluhkan tidak memiliki model operasional bertani, dengan demikian mereka banyak memanfaatkan tengkulak untuk mendapatkan pinjaman pendanaan operasional bertani. Akibatnya petani ketergantungan dengan keberadaan tengkulak, sehingga tidak mempunyai daya tawar terhadap harga jual komoditi pertanian. Petani mempunyai resiko gagal panen, resiko harga rendah ketika panen raya dan resiko terjerat bunga pinjaman dari tengkulak.

Dengan demikian peran petani penting ditingkatkan dari sisi kapasitas dan kapabilitasnya berbudidaya rumput laut. Komoditi ini memiliki daya saing ketika membudidayakan rumput lautnya melalui sistem rakit, sistem dasar lepas pantai dan sistem garis panjang (Fadli, et al., 2017). Hasil budidaya rumput laut yang berkualitas terutama untuk bahan baku karagenan dan agar penting dijaga untuk meminimalisir resiko mendapatkan rendemen yang rendah (Heti \& Geldermann, 2017). Kualitas penting ditingkatkan untuk menjaga kepercayaan industri dalam kontrak beli dengan petani. Hasil budidaya yang produktif dan terjamin kontrak belinya dengan industri akan lebih meningkatkan pendapatan petani, ditunjang dengan mekanisme pembiayaan SRG yang dapat berdaya saing dengan pembiayaan melalui, salah satunya dengan subsidi bunga dari pemerintah pusat. Subsidi bunga sudah diatur pada Peraturan Menteri Keuangan No. 171/PMK.05/2009 tentang Skema Subsidi Resi Gudang.

Pengembangan bisnis rumput laut tidak terlepas dari peran pemangku Kepentingan traderleksportir rumput 
laut. Permintaan rumput laut dunia sangat tinggi terutama untuk jenis rumput laut cottonii. Ekspor rumput laut Indonesia sebagian besar masih berupa bahan mentah khususnya rumput laut jenis Eucheuma conttonii dan Gracilaria sp yang diekspor sekitar 64\% ke berbagai negara. Rumput laut umumnya diperdagangkan dalam bentuk: (1) rumput laut kering, (2) produk yang dapat langsung dikonsumsi, dan (3) produk hidrokoloid (karaginan, agaragar, dan alginat).

Terdapat sekitar 140 negara pengimpor rumput laut Indonesia. Rumput Laut atau Alga Lainnya untuk Dikonsumsi Manusia negara pengimpor utama didominasi oleh: China $(56,95 \%)$, Jepang (13,55\%), dan Taipei (6,33\%). Rumput Laut atau Alga Lainnya tidak untuk Dikonsumsi Manusia, negara pengimpor utama didominasi oleh: China (44,38\%), Irlandia (19,58\%), dan Prancis (7,50\%). Agar-agar, negara pengimpor utama didominasi oleh: Jepang (13,57\%), Amerika Serikat (10,75\%), dan Spanyol (7,55\%). Sedangkan Karaginan, negara pengimpor utama didominasi oleh: Amerika Serikat (32,75\%), Meksiko $(22,62 \%)$, dan Filipina (7,61\%) (Trademap, diolah Kemenko, 2017 dalam lampiran Perpres 33 tahun 2019 tentang Roadmap Pengembangan Rumput Laut Nasional). Jika nilai ekspor rumput laut disesuaikan dengan harga rumput laut dunia, nilai ekspor secara keseluruhan cenderung mengalami penurunan rata-rata per tahun $4,65 \%$ (Masterplan Rumput Laut, 2017).

Industri Pengolah Rumput Laut memegang peran yang sangat penting terutama untuk hilirisasi rumput laut. Beberapa industri di Sulawesi Selatan dan Jawa mendapatkan kesulitan pembelian bahan baku karena harganya mahal dan langka di sumber penghasilnya, akibat banyaknya permintaan ekspor dan pengolahan Alkali Treated Cottonii (ATC) dari penanaman modal asing. Dalam rangka menjaga keberlangsungan pasokan bahan baku rumput laut kering, industri melakukan pembinaan langsung kepada petani. Penelitian ini menelaah pentingnya integrasi hulu ke hilir dalam rantai pasok pengembangan rumput laut yang juga perlu memanfaatkan sistem informasi teknologi berbasis aplikasi baik web maupun mobile app.

Kliring Berjangka Indonesia/Pusat Regristasi bertugas melakukan kegiatan penatausahaan Resi Gudang dan Derivatif Resi Gudang, dimana hanya dapat dilakukan oleh Badan Usaha berbadan hukum dan mendapat 
persetujuan Badan Pengawas sesuai amanat Undang-Undang Republik Indonesia No.9 tahun 2006 junto Undang-Undang Republik Indonesia No. 9 Tahun 2011 tentang Sistem Resi Gudang pada pasal 34. Didalam industri Sistem Resi Gudang di Indonesia, PT KBI (Persero) berperan sebagai Pusat Registrasi dan memiliki fungsi pencatatan, penyimpanan, pemindah bukuan kepemilikan, pembebanan hak jaminan, pelaporan serta penyediaan sistem dan jaringan informasi Resi Gudang dan Derivatif Resi Gudang.

Dengan berdasarkan ijin yang telah diperoleh dari BAPPEBTI No.03/BAPPEBTI/Kep-

SRG/SP/PUSREG/6/2009 tanggal 16 Juni 2009. Proses penatausahaan tersebut sudah dilakukan secara online. Penatausahaan Resi Gudang bertujuan agar pencatatan, penyimpanan, pemindah bukuan kepemilikan/ pengalihan, serta pembebanan hak jaminan Resi Gudang dan Derivatif Resi Gudang (baik warkat atau tanpa warkat) dapat dipantau oleh PT KBI (Persero) sebagai Pusat Registrasi, sehingga memberikan kepastian bagi pemegang Resi Gudang dan kreditur.

Penyelenggara Pasar Fisik/Lelang baik spot atau sistem penyerahan kemudian (forward) berperan penting sebagai gerbong penggerak untuk membuka akses pasar yang luas baik di dalam negeri ataupun luar negeri. Namun beberapa kendala yang terjadi pada pasar lelang adalah adanya ketergantungan penyelenggaraan pasar lelang pada anggaran Negara/ daerah. Hal ini menunjukkan signal belum optimalnya kelembagaan ini, sehingga perlu skema untuk mengintegrasikan hulu sampai dengan hilir dari rantai pasok, untuk memaksimalkan peran swasta sebagai lembaga penyelenggara terutama dalam mencari data-based pelaku dan bekerjasama dengan berbagai pihak swasta sebagai pihak penjamin transaksi serta penyiapan pembeli siaga (stand by buyer).

\section{Keep Informed/Defender}

Pemangku kepentingan pada kuadran ini mempunyai tingkat kepentingan tinggi namun pengaruh (power) nya rendah. Pemangku kepentingan pada kuadran ini terdiri dari Pengumpul Lokal. Para pengumpul lokal adalah para pembeli yang membeli rumput laut langsung kepada petani. Para pengumpul lokal ini dapat berupa koperasi atau pedagang pengumpul personal yang mempunyai modal untuk 
pembiayaan operasional petani, bahkan ada yang melakukan bisnisnya dengan cara ijon.

Bursa Berjangka Komoditi merupakan bagian penting dalam pengembangan rumput laut nasional kedepannya sebagai sarana untuk lindung nilai atau hedging (pasar futures) atas harga rumput laut yang cukup fluktuatif serta dapat membuka akses pasar internasional lebih luas. Bursa berjangka belum mempunyai kontrak futures untuk komoditi rumput laut. Harga rumput laut ditentukan oleh pembeli atau eksportir luar negeri dan dengan menggunakan sistem kontrak fisik sehingga belum menarik bagi bursa berjangka disamping mereka belum mengenal peluang komoditi rumput laut secara mendalam serta pentingnya manfaat interkoneksi pasar fisik (spot) berbasis SRG dengan pasar berjangka.

Asosiasi Rumput Laut mempunyai kepentingan rendah dan kekuatan rendah karena dua asosiasi rumput laut yang ada merupakan asosiasi penghasil rumput laut dan pengolah rumput laut yang belum mempunyai peran signifikan terhadap pengembangan rumput laut berbasis sistem resi gudang. Beberapa anggota asosiasi masih belum memberikan respon yang serius untuk memanfaatkan pembiayaan resi
Gudang pada bisnisnya serta belum memahami manfaat SRG sebagai sarana tunda jual, kepastian pasokan dan jaminan bahan baku kualitas rumput laut. Asosiasi perlu terus dirangkul dan dilibatkan dalam pengembangan rantai pasok, karena mereka sangat berperan dalam aktivitas produksi, logistik dan pemasaran baik di dalam dan luar negeri (Dobrzynsi, et al., 2015).

\section{Keep Satisfied/Latent}

Latent berada pada kuadran III yang mempunyai pengaruh tinggi namun kepentingannya rendah. Pemerintah daerah merupakan pemangku kepentingan yang mempunyai pengaruh untuk berjalannya pengembangan rumput laut. Pengembangan budidaya rumput laut dan pengembangan Sistem Resi Gudang di daerah dipengaruhi oleh keberpihakan pemerintah daerah. Dengan demikian beroperasinya Gudang SRG yang dibangun pemerintah pusat sangat terpengaruh oleh keberpihakan pemerintah daerah dalam mengoperasikannya.

Lembaga Keuangan Bank merupakan bank yang melakukan penyaluran pembiayaan dalam sistem resi Gudang. PMK 171/PMK.05/2009 tentang Skema Subsidi Resi Gudang 
(S-SRG) \& Permendag Nomor 66/MDAG/PER/12/2009

tentang

Pelaksanaan Skema Subsidi Resi

Gudang. Beban bunga kepada Peserta S-SRG (Petani, Kelompok Tani, Gapoktan, Koperasi) ditetapkan sebesar $6 \%$. Selisih tingkat bunga SSRG dengan beban bunga Peserta SSRG merupakan subsidi Pemerintah. Bank yang sudah menyalurkan kreditnya di S-SRG antara lain Bank BRI, Bank BJB, Bank Jatim, Bank Jateng, Bank Kalsel, Bank Sumut dan Bank Lampung.

Lembaga Keuangan Non Bank merupakan pembiayaan SRG yang dilakukan oleh beberapa Program Kemitraan Bina Lingkungan (PKBL) dari beberapa Badan Usaha Milik Negara (BUMN), misalnya dari PT. Kliring Berjangka Indonesia (PT. KBI) dan Lembaga Pengelola Dana Bergulir (LPDB) dari Kementerian Koperasi dan UMKM.

Lembaga Penilai Kesesuaian merupakan suatu Lembaga yang sudah disahkan melalui ijin dari Komite Akreditasi Nasional (KAN) sesuai dengan amanat Undang-Undang No. 20 Tahun 2014 tentang Standardisasi dan Penilaian Kesesuaian adalah kegiatan untuk menilai bahwa Barang, Jasa, Sistem, Proses, atau Personal telah memenuhi persyaratan acuan. Lembaga Penilai Kesesuaian (LPK) bekerja dalam menguji mutu berdasarkan dengan Standar Nasional Indonesia (SNI). SNI pengujian kadar air rumput laut mengacu pada SNI-26902015 dengan metode uji sesuai dengan SNI-01-2354-2006. Mengingat Pemerintah Daerah, lembaga pembiayaan dan LPK punya peran penting dalam keberhasilan SRG, maka perlu komunikasi yang intensif dan fasilitasi (program edukasi, infrastruktur, dII) kepada mereka untuk didorong dapat masuk ke dalam kuadran promoter kedepannya.

\section{Monitor (Minimum Effort)/Apathetic}

Kuadran I atau disebut dengan apathetic merupakan kuadran dengan nilai kepentingan rendah dan nilai power juga rendah. Pemangku kepentingan pada kuadran ini adalah masyarakat. Masyarakat lokal terutama di pesisir mempunyai peran penting dalam mendukung berjalan dan berkembangnya rantai pasok rumput laut. Sosialisasi kepada masyarakat mengenai kebijakan terkait Sistem Resi Gudang dan Pasar Lelang Komoditas yang sudah diinisiasi untuk diintegrasikan penting untuk dilakukan.

Dengan demikian masyarakat lokal perlu dilibatkan langsung 
pengembangan rantai pasok hasil analisis matriks pemetaan pengembangan rumput laut berbasis stakeholder maka pemangku sistem resi Gudang, dari hulu sampai kepentingan pada kuadran Manage dengan hilir (Vredegoor \& Pennink, Closely/Promoter ini perlu dikelola 2013). Komunitas masyarakat secara intensif dan terus menerus umumnya tidak mendapatkan dilibatkan dalam pembinaan dan keuntungan langsung dari pengembangan SRG pada rantai pasok komoditi pertanian, namun akan mendapatkan dampak peningkatan ekonomi karena adanya pembangunan dan bekembangnya budidaya dan pengolahan komoditi seperti yang sudah terjadi di Ghana (Mario et al., 2018). Kedepannya penting untuk terus disosialisasikan tentang skema resi Gudang untuk membantu operasional budidaya rumput laut sehingga masyarakat mengenal dengan baik dengan skema sistem resi Gudang sebagai alternatif solusi pembiayaan dan pemberdayaan ekonomi masyarakat.

\section{KESIMPULAN DAN REKOMENDASI KEBIJAKAN}

Berdasarkan hasil identifikasi pemangku kepentingan menunjukkan bahwa terdapat 15 pemangku kepentingan yang terlibat dalam rantai pasok bisnis rumput laut berbasis SRG di Indonesia. Dimana terdapat sembilan pemangku kepentingan kunci dan enam pemangku kepentingan penunjang. Dari

pelaksanaan Sistem Resi Gudang yang terkoneksi integratif dalam rantai pasok dari hulu hinga hilir serta pasarnya. Untuk pemangku kepentingan lainnya perlu disiapkan strategi komunikasi yang efektif guna merangkul mereka agar berpartisipasi dan berkontribusi dalam percepatan implementasi terus melakukan pendekatan, fasilitasi, monitoring dan pemberian informasi yang jelas dan masif.

Beberapa strategi untuk mempertahankan peran pemangku kepentingan terhadap realisasi dari pengembangan rumput laut antara lain dengan (a) memperlakukan mereka dengan respek, (b) memberi informasi apapun, training, mentoring, dan/atau dukungan yang diperlukan agar mereka tetap terlibat, dan (c) melibatkan mereka dalam pengambilan keputusan

Rekomendasi yang diberikan dari hasil kajian ini adalah perlu adanya peningkatan pelayanan dan kehandalan stakeholder kelembagaan dalam SRG terutama untuk penerbitan dan pencairan kredit Resi Gudang maksimal 
dalam 3 (tiga) hari melalui peningkatan penyiapan pengelola gudang, lembaga penguji mutu dan lembaga keuangan di daerah serta implementasi pembentukan lembaga penjaminan SRG. Disamping itu, perlu adanya penyiapan pasarnya (offline maupun online) dengan fasilitasi Kementerian Perdagangan dan $\mathrm{K} / \mathrm{L}$ terkait bersinergi dengan pelaku usaha/Asosiasi rumput laut termasuk pembeli siaga (trader, eksportir dan industri pengolahan) bagi barang yang di resi gudangkan yang sangat penting bagi pihak perbankan/lembaga pembiayaan non bank serta para petani dan pelaku usaha yang terlibat.

Pemanfaatan implementasi Teknologi Informasi pada seluruh rantai pasok rumput laut penting terutama membuka akses pasar bagi pelaku usahanya termasuk UKM dan koperasi melalui e-commerce serta pengumpulan dan pengolahan data/informasi yang cepat dan akurat terutama terkait kalender tanam/budidaya, jumlah pasokan serta kualitas dan harga komoditi.

Berkenaan hal-hal tersebut diperlukan evaluasi lebih lanjut terhadap kebijakan pemerintah terutama di tingkat peraturan pelaksanaan (tingkat Menteri dan Badan Pengawas SRG) khususnya terkait pengaturan lembaga penguji mutu dan standar mutu rumput laut (SNI), jenis komoditi yang dapat masuk SRG dan persyaratan pengelola gudang SRG yang sesuai dengan kondisi lapangan. Disamping itu perlu penelitian lanjutan secara komprehensif terkait model bisnis integrasi hulu-hilir dalam industri rumput laut berbasis sistem resi gudang dan perumusan strategi kebijakannya dalam menghadapi era ekonomi digital pada revolusi industri 4.0 ini.

\section{UCAPAN TERIMA KASIH}

Penulis mengucapkan terima kasih kepada para dosen dan civitas akademika Sekolah Bisnis Institut Pertanian Bogor yang telah memberikan perhatian dan bimbingan sehingga dapat selesainya penulisan artikel ini. Demikian pula diucapkan terimakasih kepada Kepala Badan Pengkajian dan Pengembangan Perdagangan (BP3), Sekretaris BP3 dan jajarannya serta pihak Badan Pengawas Perdagangan Berjangka Komoditi Kementerian Perdagangan dan berbagai pihak terkait yang telah pula memberikan bantuan dan dukungannya.

\section{DAFTAR PUSTAKA}

Badan Pengawas Perdagangan Berjangka Komoditi (BAPPEBTI). (2018). slide presentasi sosialisasi Sistem Resi Gudang. Jakarta 
Berland, N.J., Klakeg, O.J., \& Sefland, A. M. (2014). Stakeholder Management Fieldbook, Get Started With Stakeholder Management. Nils Jacob Berland and Elin Stoveland. Norwegia.

Brugha, R., \& Varvasovszky, Z. (2000). Stakeholder analysis: a review. Health Policy and Planning, 15(3), 239-246.

Bryson, J. M. (2003). What to do when stakeholders matter: $A$ guide to stakeholder identification and analysis techniques. Washington, D.C.: George-town University Public Policy Institute.

Bryson, J. M. (2004). What to do when stakeholders matter. Public Management Review, 6(1), 21-53.

Dobrzynski, M, Dziekonski, K \& Jurczuk, A. (2015). Stakeholder Mapping-A Case of International Logistic Project. Polish Journal of Management Studies. Vol 11(2), pp. 17-26.

Fadli, R., Pambudy \& Harianto. (2017). Analisis Daya Saing Agribisnis Rumput Laut di Kabupaten Lombok Timur. Jurnal Agribisnis Indonesia. Vol 5(2), pp. 89-102.

Gonsalves, J., Becker, T., Braun, A., Campilan, D., Chaves, H. De, Fajber, E., Vernooy, R. (2005). Participatory research and development for sustainable agriculture and natural resource management (Vol. 1). International Potato Center-Users' Perspectives with Agricultural Research and Developmant, Laguna, Philippines and International Development Research Centre, Ottawa, Canada: A Sourcebook.

Hallikas, J., Karvonen, I., Pulkkinen, U., Virolainen, V.M. dan Tuominen, M. (2004). Risk management processes in pemasok network. Vol.90 (1) pp. 47-58.

Hermans, L.M \& Thiessen, W.A.H. (2008). Actor Analysis Methods and Their Use for Public Policy Analysis. European Journal of Operational Research Vol.
(19) 6, pp. 808-818. http://dx.doi.org/10.1016/j.ejor.2008.0 3.040

Heti, M \& J. Geldermann. (2017). Managing Risk in The Indonsian Seaweed Supply Chain. Clean Technology Environmental Policy. Vol 19(1), pp. 175-189.

Hikmah, N. (2016). Peningkatan Hasil Belajar Matematiak Tentang Penjumlahan dan Pengurangan Bilangan Bulat Melalui alat Peraga Mistar Bilangan. Jurnal Pedas Mahakam Vol. 1(1), pp. 80-85.

Hubacek, K., Prell, C., Reed, M., Qiunn, C., Jin, N., Holden, J., Sendzimir, J. (2007). If you have a hammer everything looks like a nail: 'traditional' versus participatory model building. Inter- disciplinary Science Reviews. Vol. 32(3), pp. 1-20.

lqbal, M. (2007). Analisis peran pemangku kepentingan dan implementasinya dalam pembangunan pertanian. Jurnal Litbang Pertanian, 26(3). Pp. 15-22

Khan, M., Tariq, N., Khan, A., Mahmood, K. (2012). An organizational concept of human resource development - How human resource management scholars view 'HRD' (Literature Review). Universal Journal of Management and Social Sciences, Vol. 2(5), pp. 36-47.

Mario, J. M., F.M, Mulangu, F.M. Kemeze, S. Kolavalli. (2018). Does Warehouse Receipt Financing Benefit Ghanaian Smallholders?. Strategy Support Programe. Vol 13, pp. 1-3.

Nurfatriani, F., D. Darusman, D. R. Nurrochmat dan A. E. Yustika. (2015). Analisis Pemangku Kepentingan dalam Transformasi Kebijakan Fiskal Hijau. Jurnal Analisis Kebijakan Kehutanan. Vol 12(2):105-124.

Peraturan Presiden nomor 33 tahun 2019 tentang Roadmap Pengembangan Rumput Laut Nasional. Lembar Negara Republik Indonesia 
Race, D. \& J. Millar. (2008). Training Manual: Social and cimmunity dimensions of ACIAR Training Manual. Australian Center for International Agricultural Research Institute for Land, Water, and Society of Charles Sturt University, Australia. 4,33 pp. ISBN:978 1

Rajablu M, G. Marthandan \& W.F.W Yusoff. (2018). Managing for Stakeholders: The Role of Stakeholders-Based Management in Project Success. Asian Social Science. Vol 11(3), pp. 111-125.

Raydais, A.E \& M. Damayanti. (2018). Peran dan Kapasitas Pemangku Kepentingan Program RPM Dalam Mendukung Ketersediaan Pangan Melalui Produksi Padi di Kecamatan Malaka Tengah, Kabupaten Malaka, Provinsi NTT. Jurnal Pembangunan Wilayah dan Kota. Vol 14(3), pp. 143155.

Reed, M. S., Graves, A., Dandy, N., Posthumus, H., Hubacek, K., Morris, J., . . Q Quinn, C. H. (2009). Whos in and why? A typology of stakeholder analysis methods for natural resource management. Journal of Environmental Management, ol 90(1), pp.1933-1949.

Roslinda, E., Darusman, D., Suharjito, D., \& Nurrochmat, D. R. (2012). Analisis pemangku kepentingan dalam pengelolaan Taman Nasional Danau Sentarum Kabupaten Kapuas Hulu. Jurnal Manajemen Hutan, Vol.18(2), pp.78-85.

Sarinah \& T. Djatna. (2015). Analisis Strategi Penanganan Resiko
Kekurangan Pasokan Pada Industri Pengolahan Rumput Laut: Kasus di Sulawesi Selatan. Agritech Vol. 35(2). pp. 223-233.

Sarinah, S. Maarif, H. Hardjomidjojo, \& L. Adrianto. (2017). A Conceptual Model Design of Seaweed Agroindutry Logistic System: A Case Study in The South Sulawesi, Indonesia. International Journal of Sciences: Basic and Applied Research (IJSBAR). Vol 36(2), pp. 110-125.

Shalendra, M.S. Jairath, E. Haque, Anu, P.V. (2016). Issues Limiting the Progress in Negotiable Warehouse Receipt (NWR) Financing in India. Agricultural Economics Research Review. Vol 29(1), pp. 53-59. DOI: 10.5958/0974-0279.2016.00018.5

Solaimani, S., Guldemond, N., \& Bouwman, H. (2013). Dynamic stekeholder interaction analysis: Innovative smart living design cases. Electron Markets, Vol. 23 (1), pp. 317-328.

Vredegoor, M.T.J \& B.J.W. Pennink. (2013). Indcluding Capabilities of Local Actors in Regional Economic Development, Empirical Result of Local Seaweed Industries in Sulawesi. The South East Asian Journal of Management, Vol. 7(2), pp. 61-88. DOI10.21002/seam.v7i2.2025

Yavuz, F., \& Baycan, T. (2014). Stakeholder-based decision making in integrated watershed management using SWOT and analytic hierarchy process combination. International Journal of the Analytic Hierarchy Process, 6(1). pp. 45-60. 
